\title{
A GEÓGRAFA ISABEL ANDRÉ NOTAS DE TESTEMUNHO DE UM PERCURSO INOVADOR, BRILHANTE E LIVRE ${ }^{\mathrm{i}}$
}

Patrícia Pedro RêGO

Se eu tiver que morrer

Vou morrer pela vida!

Vinicius de Moraes

Isabel André faz parte da geração entusiasta que chegou ao Departamento de Geografia da Faculdade de Letras da Universidade de Lisboa, no imediato pós-25 de Abril de 74.

Espírito brilhante, vivo, confiante e amante dos debates, impôs os seus pontos de vista e interessou-se geograficamente pelas novas temáticas sociais que o contexto revolucionário fazia chegar à Academia nesses anos de formação.

Pioneira em muitas iniciativas e decisões, desde logo na maternidade que abraçou no limiar da idade adulta, antes ainda de chegar à Universidade, Isabel André associava a paixão à racionalidade numa medida desconhecida para a maioria dos seus contemporâneos. Exemplo da harmonização surpreendente entre um pensamento racional de que não abdicava (dizia, com frequência, "vou pensar no assunto...") e o entusiasmo, a paixão, perante cada nova descoberta (os novos conceitos, as interacções que se evidenciavam, os actores em presença, o papel dos lugares...), a sua forma de viver traduziu-se na afirmação da integridade, evidenciada no seu percurso pessoal e profissional, e expressa num exercício constante de liberdade. Havia na Isabel André a generosidade da partilha das suas experiências e dos seus projectos com os outros, convocando-os para o seu círculo próximo, numa medida maravilhosa, didáctica e incentivadora, embora adepta da autonomia de cada uma e de cada um. A sua vivência integradora, particularmente atenta aos mais jovens, beneficiou os seus alunos, os discípulos, a família, os amigos. Era, contudo, exigente porque queria construir um caminho novo.

Desde muito cedo (finais dos anos 70) Isabel André colaborou na investigação, no Centro de Estudos Geográficos, na linha de acção Estudos para o Planeamento Regional e Urbano. A economia e a política sempre a interessaram e, para além do contributo em projectos de planeamento, colaborou nos estudos pioneiros na temática da Geografia Eleitoral a que dedicou, aliás, a sua tese de mestrado em 1984.

Professora Auxiliar, Departamento de Geociências, Universidade de Évora, Colégio Luís António Verney, Rua Romão Ramalho, 59, 7000-671 Évora, Portugal. E-mail: patrego@uevora.pt 
Foram anos de encantamento, esses anos de formação em que a Escola de Lisboa era bafejada pelas novas correntes de pensamento que envolviam os estudantes de várias gerações, ao mesmo tempo que se beneficiava da presença dos mais velhos mestres.

Foi nas primeiras aulas do Curso de Geografia que conheci a Isabel Margarida, uma inteligência generosa, aberta à amizade e à partilha, num momento em que todos nós, jovens estudantes, nos fascinávamos com a Geografia e com tudo aquilo que através dela aspirávamos concretizar, do ponto de vista profissional.

Amante da escola, de aprender mas também da reflexão sobre o modo de transmitir conhecimento, iniciou, em 1980, o percurso profissional na Academia, como docente no Departamento de Geografia na Universidade de Lisboa. Um pouco mais tarde (1992), partilhou com colegas e amigos a experiência do planeamento, da consultoria e da avaliação de políticas públicas na empresa Geoideia. Esta iniciativa proporcionou à Isabel Margarida o alargamento da sua rede de amigos ao mesmo tempo que diversificou a sua experiência profissional. Alguns desses amigos acompanharam sempre a sua vida, nomeadamente porque para além de um trabalho ou de um estudo específico foi tecendo relações humanas que fidelizou. Assim, também através dos amigos desenvolveu a sua ligação estreita a lugares (cidades) particulares que, além de Lisboa, fazem parte da sua geografia pessoal: Barcelona, Bruxelas, Madrid, Paris, Montreal, Quebec, Horta, Montemor-o-Novo...

A construção do seu percurso académico é marcada pelos temas de investigação inovadores, ligados às suas vivências, preocupações ou sensibilidade pessoal. É, naturalmente, o caso da sua dissertação de doutoramento em Geografia Humana, pela Universidade de Lisboa (1994), intitulada "O falso neutro em Geografia Humana: género e relação patriarcal no emprego e no trabalho doméstico”. Para além de ser um estudo pioneiro na Geografia do Género, esta tese recebeu um prémio numa cerimónia a que assisti, na Biblioteca Municipal do Palácio Galveias, no Campo Pequeno. Contudo, o facto não aparece no currículo e, assim, todos temos dificuldade de nomear a distinção. Recordo ainda que o prémio incluía o interesse na publicação da dissertação mas, fruto da característica da Isabel Margarida em focar-se na investigação seguinte, uma vez terminados os trabalhos desenvolvidos, a iniciativa não se concretizou.

Os estudos de género conferiram o maior reconhecimento à Isabel Margarida, durante a sua vida académica. Assim, por exemplo, em projectos internacionais onde participou, mesmo não sendo essa a temática central do seu contributo, era solicitada como especialista das ciências sociais nos estudos de género. Depois, numa sequência natural, alargou a sua investigação de Geografia Social à saúde reprodutiva da mulher, aos maus tratos às crianças e jovens, ao abandono escolar. Estas temáticas, em que as crianças e a família estão no centro da reflexão, são-lhe caras até porque as crianças voltam a estar muito presentes na sua vida por via da chegada dos netos, na viragem do século. Quanto a estes estudos, decorrem de uma longa parceria com investigadores do Instituto de Ciências Sociais (ICS) da Universidade de Lisboa, iniciada em 1995.

Antes de mais professora, associava cada cara familiar, percepcionada num encontro fora da Universidade, a um aluno de geografia ${ }^{\mathrm{ii}}$. Entretanto, testemunhei, por diversas vezes, antigos alunos que se lhe dirigiam na rua, fazendo referência entusiasta às suas aulas e ao seu contributo para o interesse em estudar geografia.

Os temas ligados ao ensino e às metodologias de investigação, com particular interesse nos instrumentos metodológicos destinados a estimular os processos de aprendizagem activa, o pensamento crítico e as metodologias participativas, foram trabalhados em estreita relação e parceria com outros colegas do ex-departamento de Geografia da Faculdade de Letras, entretanto integrado no Instituto de Geografia e Ordenamento do Território (IGOT-UL). Adepta da inovação, e confiante no futuro, viveu com entusiasmo a autonomização da Geografia e com dedicação a criação do Instituto, em 2009. 
Desde 2004, com os projectos que liderou e em que participou, quer nacionais como europeus, a sua investigação orientou-se para os processos de inovação sócio-territorial e o desenvolvimento urbano, para as práticas de governança socialmente inovadoras, para o estudo do papel da cultura e das artes na regeneração dos lugares.

Estes novos e fortes interesses de pesquisa resultaram do encontro com outros colegas investigadores, quer no Centro de Estudos Geográficos, quer na Newcastle University e KU Leuven. O sucesso da nova etapa deveu-se tanto às qualidades de liderança da Isabel Margarida, como ao facto de ter sabido congregar à volta destes temas um conjunto ímpar de jovens bolseiros de investigação: o Alexandre Abreu, o André Carmo, a Ana Estevens, o Leandro Gabriel.

O notável percurso geográfico da Isabel Margarida André foi sendo solidamente construído através de problematizações que se foram sucedendo, como tentei exemplificar. Não foi um caminho solitário e tive o enorme privilégio de fazer parte dos que a acompanharam desde o início. Gostávamos muito uma da outra. Eu adorava a sua inteligência, o seu entusiasmo, a sua decisão, o modo como geria o tempo. Com ela tudo parecia possível. O convite que me foi endereçado para escrever esta nota é a primeira oportunidade que tenho de fazer uma reflexão sobre a vida da minha amiga de sempre, de ganhar sobre ela uma nova perspectiva que a engrandece porque o seu legado à Geografia é muito significativo. E agora? Só temos que retomar a leitura dos seus textos, recordar a universalidade do seu espírito e continuar caminhando.

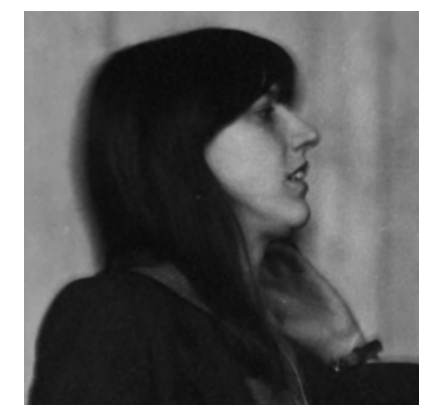

Isabel André, Jubileu do Professor Orlando Ribeiro em 1981

Faculdade de Letras da Universidade de Lisboa.

Fotografia da autoria de Ilídio do Amaral

i Agradeço ao geógrafo Fernando João Moreira, companheiro de vida da Isabel André, a generosidade de ter sido o primeiro leitor deste texto e os seus comentários.

ii O Fernando João Moreira contava o episódio do reconhecido jogador de futebol a quem a Isabel Margarida perguntou, num hotel de Liubliana, "foi meu aluno...?". 